\title{
SIR WARINGTON WILKINSON SMYTH, M.A., F.R.S.
}

For. Sec. Geol. Soc., F.R.G.S.; Lecturer on Mining at the Royal School of Mines, and Inspector of Mineral Property of the Duchy of Cornwall and the Crown.

\section{Born 1817; Died 19Th June, 1890.}

Sir Warington W. Snyth (whose sudden death from heart disease we recorded in our last Number) was the eldest son of Admiral W. H. Smith, D.C.L., F.R.S., etc., and was born in 1817 at Naples. His mother was the only daughter of Mr. Thomas Warington, British Consul at that city. He was educated at Westminster and Bedford Schools and Trinity College, Cambridge, where he distinguished himself, among other ways, as an oarsman, rowing in the winning University Crew on the Thames in 1839. In this year he took his B.A. degree, and, having gained a travelling bachelorship, commenced a journey which extended over a period of more than four years, and was mainly devoted to a study of the mineral products and mining industries of Germany, Austria, Hungary, European Turkey, and Asia Minor, in the course of which he laid the foundation of that solid and practical knowledge of these subjects which made him thronghout his life one of our greatest authorities upon them. On his return to England in 1844, he was appointed by Sir Henry De la Beche to a post on the Geological Survey, and in 1851, on the formation of the Royal School of Mines in Jermyn Street, he became Lecturer on Mineralogy, and on Mining, retaining the former chair till 1881, and the latter to his death. About the same time he was appointed Inspector of the Mineral Property of the Duchy of Cornwall, and soon afterwards Chief Mineral Inspector to the Crown, under the Commissioners of Woods, Forests, and Land Revenues. For the Geological Society he has done good service, having been one of the Honorary Secretaries from 1856 to 1866, President in 1866 and 1867, and Foreign Secretary for the last 16 years. In 1879 he was appointed Chairman of the Royal Commission on Accidents in Coal Mines, to the duties of which office he devoted much labour, in addition to the performance of his ordinary professional work during the seven years in which the Commission was sitting. For this and other public services he received the honour of knighthood in 1887. Besides various technical reports and contributions to purely scientific literature, he published in 1806 a book entitled "A Year with the Turks," and in 1867 "A Rudimentary Treatise on Coal and Coal Mining," a standard work now in its sixth edition, which has been translated into the principal European and also the Chinese languages. Although he was not a man who cared much to place himself before the world, he commanded the respect and esteem of all who came into contact with him in no common degree, and it will be difficult to replace him in the particular branches of Science which be had made especially his own. He may be said almost to have died in harness; for, notwithstanding that he bad been for some months out of health 
to such an extent as to cause anxiety in the minds of his intimate friends, he could scarcely be persuaded to give himself any relaxation from his official labours, the scrupulously conscientious performance of which had characterized him throughout life, and he attended the soirée of the Royal Society on June 18th, the evening before his death. Sir Warington Smyth married, in 1864, Antonia, daughter of the late A. M. Story-Maskelyne, of Basset Down, Wilts, and he leaves two sons.

As a lecturer on Mining to students he was most popular, and his discourses were amongst the most largely attended of any of those delivered at the Royal School of Mines. These lectures were never published, but a short-hand report of the course, taken by a writer employed by Prof. John Milne, F.R.S., of Tokio, Japan, when he was himself one of Prof. Smyth's students, and afterwards privately printed, exists in the archives at Jermyn Street. It would be a pleasing memorial to Sir Warington Smyth, if some of his old students undertook to reprint these (after being carefully edited), and issued them as a testimonial of their love and esteem for their Professor.

\section{ROBERT WILLIAM MYLNE, F.R.S., F.G.S. Born, June 14, 1816 ; Died, Juty 2, 1890.}

We regret to record the death of another old member and past officer of the Geological Society of London. Mr. R. W. Mylne, F.R.S., who died on the 2nd July, 1890, in his 75th year.

By profession Mr. Mylne was a Civil Engineer and Architect, particularly directing bis attention to matters concerning the Watersupply of large towns. This special bias to his career was doubtless greatly due to the fact that his father held the post for fifty years of Engineer to the New River Company. Although not himself an official of that Company, he took part in engineering work required by them, in association with his father, for about twenty years. The knowledge so obtained is shown in his evidence before the Royal Commission on Water-Supply on the 6th June, 1867, and in his paper "On the Supply of Water from Artesian Wells in the Jondon Basin, with an account of the Sinking of the Well at the Reservoir of the New River Company at Hampstead Road ;" I and in his work published in 1850, "Sections of the London Strata," in which many "deep wells" of those days are recorded, but none of them pass through the Chalk; the deepest being 522 feet.

About 1857 he published a Contour Map of the Metropolis, and in 1871 a similar map, geologically coloured, appeared. $\mathrm{He}$ was elected a Fellow of the Geological Society of London in 1848; and was on the Council of that Society from 1854 to 1868 , and again in 1879. In the years 1856 and 1857 he held office as one of the Secretaries, the other being the late Sir Warington W. Smyth, F.R.S. He was elected a Fellow of the Royal Society in 1860. For many years he served the office of Treasurer to the Geological Club.

W. R. J.

1 Trans. Inst. Civil Eng. vol. iii. pp. 234-244, 1842. This includes Reports by W. C. Mylne and J. Simpson. 